\title{
PREFACE
}

\section{Composite Tissue Allograft Transplantation}

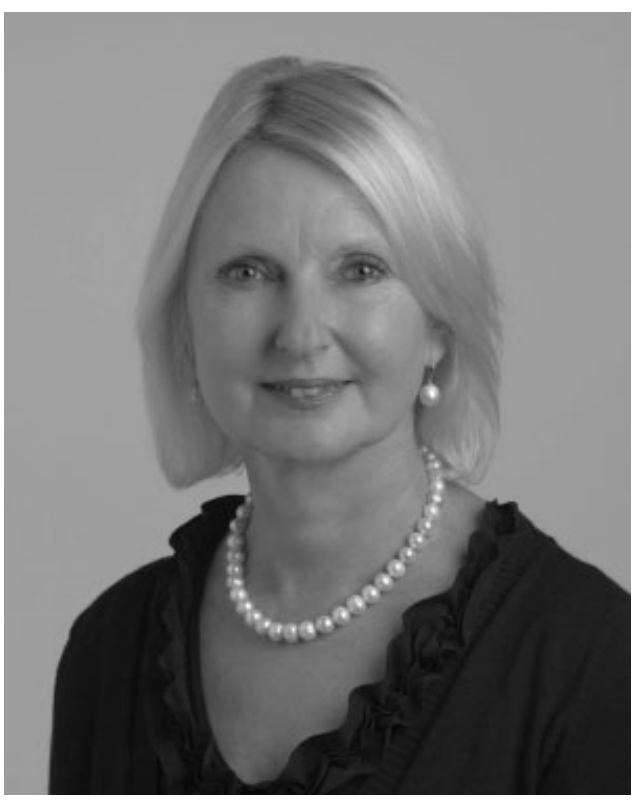

Maria Siemionow, M.D., Ph.D., D.Sc.

$\mathrm{I}_{\mathrm{t}}$ is a pleasure to introduce to Seminars in Plastic Surgery the topic of composite tissue allograft transplantation. This new emerging field is of special interest to plastic surgeons because it opens new reconstructive options for patients with complex deformities, which are difficult to treat with conventional procedures currently available in plastic surgery. Composite tissue allograft transplantation requires microsurgical skills combined with basic reconstructive techniques that have been applied for years in plastic surgery. The clinical applica- tions of composite tissue allograft transplants including human hand, abdominal wall, larynx, trachea, nerve, tendon, muscles, tongue, and partial face transplantation become clinical reality. For this volume of Seminars in Plastic Surgery, I have invited experts in the field to share their experience with different types of composite tissue allografts applied in a clinical practice. Drs. Bozulic, Breidenbach, and Ildstad summarize their experience with hand transplantation and outline strategies for tolerance induction in composite tissue allografts. Drs. Khariwala, Lorenz, and Strome present their experimental research and long-term follow-up on the first laryngeal transplant. Drs. Fox and Mackinnon describe their unique approach to vascularized nerve allograft transplantation. Drs. Guimberteau, Bakhach, and Casoli share their experience with the first vascularized tendon allograft transplant and outline strategies for preservation of the small composite tissue organ transplants. Finally, we summarize our experience with experimental models applied to research on composite tissue allografts and our approaches in preparation for facial transplantation.

It is clear that composite tissue allografts have become a part of the plastic and reconstructive surgery armamentarium. I hope that this issue of Seminars in Plastic Surgery will be a valuable addition to training surgeons and to those who would like to incorporate composite tissue allograft transplantation into their routine clinical practice in the near future.

$$
\begin{array}{r}
\text { Maria Siemionow, M.D., Ph.D., D.Sc. }{ }^{1} \\
\text { Guest Editor }
\end{array}
$$

\footnotetext{
${ }^{1}$ Department of Plastic Surgery, The Cleveland Clinic, Cleveland, Ohio.

Address for correspondence and reprint requests: Maria Siemionow, M.D., Ph.D., D.Sc., Department of Plastic Surgery, The Cleveland Clinic, 9500 Euclid Avenue Cleveland, Ohio 44195.

Composite Tissue Allograft Transplantation; Guest Editor, Maria
}

Siemionow, M.D., Ph.D., D.Sc.

Semin Plast Surg 2007;21:203-204. Copyright (C) 2007 by Thieme Medical Publishers, Inc., 333 Seventh Avenue, New York, NY 10001, USA. Tel: +1(212) 584-4662.

DOI 10.1055/s-2007-991189. ISSN 1535-2188. 